\title{
URINE AND SERUM SOLUBLE INTERLEUKIN 7 RECEPTOR LEVELS IN PATIENTS WITH SYSTEMIC LUPUS ERYTHEMATOSUS AT ZAGAZIG UNIVERSITY HOSPITALS
}

Mazen Mohamed El-Sheikh, M.D*, Fadya Abd-Allah Abd-El-Ghany, M.D*, Yousry Elsaid Abo Elmagd, M.D**, Rofaida Abdel Hafeez Mohamed, M.Sc*

Rheumatology and Rehabilitation Department*, Biochemistry Department**. Faculty of Medicine, Zagazig University.

\begin{abstract}
Background: Soluble interleukin 7 receptor (sIL7R) is secreted by fibroblasts after stimulation with proinflammatory cytokines. SIL7R has been implicated in many autoimmune diseases such as rheumatoid arthritis (RA), inflammatory bowel diseases (IBD) and graft-versus-host disease (GVHD).

Objectives: we aimed to evaluate urine and serum sIL7R levels in patients with systemic lupus erythematosus and their association with the disease activity.

Subjects and methods: For a case control study, 54 patients with systemic lupus erythematosus and 27 age and sex matched healthy controls were involved. Serum and urine sIL7R levels $(\mathrm{ng} / \mathrm{mL})$ were determined by a sandwich ELISA kit. Disease activity was measured by SLE disease activity index (SLEDAI) score, complement C3, C4 levels and anti-dsDNA titre.

Results: Serum sIL7R levels were significantly higher in SLE patients $(p<0.0001)$ than in control group . Patients with lupus nephritis had significantly higher serum levels of sIL7R than those without nephritis . There was significant correlation between sIL7R levels and SLE disease activity including SLEDAI, C3,C4, anti dsDNA. Urine levels of sIL7R showed non-significant difference between SLE patients and control group and did not correlate with disease activity.
\end{abstract}

Conclusions: Serum sIL7R is a valuable marker of SLE disease activity, especially in patients with lupus nephritis.

Keywords: Systemic lupus erythematosus, soluble interleukin 7 receptors, SLEDAI.

\section{Corresponding author: Rofaida Abdel Hafeez}

Tel: 01008666543

Email : dr.rofida12@hotmail.com.

\section{INTRODUCTION}

Oystemic lupus erythematosus (SLE) is an autoimmune disease of unknown etiology, which mostly occurs in women of childbearing age. SLE is mainly caused by immune dysregulation with increased autoantibodies formation and immune complex deposition. [1].

SLE has a wide spectrum of severity, ranging from mild manifestations (e.g. skin rash or non-erosive arthritis) to severe or life threatening complications, such as lupus nephritis, neuropsychiatric disorders and other major organ involvements. [2].

The pathogenesis of SLE entails a complex interaction between the different arms of the immune system. SLE is attributed mainly to autoantibodies and immune complex deposition. However, mounting evidence has suggested that cytokines are also involved in the pathogenesis of SLE. [3].

The complicated pathogenesis and varied clinical symptoms of SLE lead to great challenges in the diagnosis and monitoring of this disease. Several cytokines, their proteins and genes expression profiles may serve as markers of disease activity and severity. Moreover, biologic agents that target specific cytokines may represent novel therapies for Systemic lupus erythematosus. [4].

Interleukin-7, like other cytokines is a pleiotropic (act on many different target cells) immune regulatory protein predominately produced by immune cells such as $\mathrm{T}$ cells, natural killer cells, monocytes and stromal or non-haematopoietic cells. [5].

IL-7 mediates its actions via engagement to its specific receptor IL7R, which is a heterodimer, consists of two subunits, interleukin 7 receptor- $\alpha$ (CD127) and common- $\gamma$ chain receptor (CD132). There are two forms of the IL7R $\alpha$ chain as well, including membrane-bound (mIL-7R) and soluble form (sIL7R) of IL7R mainly secreted by fibroblasts. [6]. 
IL-7 functions primarily as a growth and anti-apoptotic factor for $\mathrm{B}$ and $\mathrm{T}$ cells. It also stimulates $\mathrm{B}$ and $\mathrm{T}$ cell lymphopoiesis. It enhances the growth of natural killer (NK) cells and promotes growth and differentiation of $\mathrm{T}$ cells. It enhances the generation of cytotoxic T Cells. [7].

IL-7 has been demonstrated as a cofactor that is implicated in several autoimmune diseases, including rheumatoid arthritis [8,9], type I diabetes [10,11], multible sclerosis [12,13] and autoimmune colitis [14].

Moreover, IL-7 pathway has been implicated in the pathogenesis of SLE. IL-7 can stimulate IL7R $\alpha$ positive T cells to secret Th1 and Th17 associated cytokines, such as interferon $\gamma$ and IL-17, which play an important role in SLE pathogenesis. [15].

In this study we aimed to assess serum and urine levels of sIL7R in systemic lupus erythematosus (SLE) patients and correlate them with the disease activity.

\section{SUBJECT AND METHODS}

This case control study included 54 patients with systemic lupus erythematosus and 27 apparent healthy subjects as control group. SLE patients were randomly selected from Rheumatology and Rehabilitation Department, Zagazig University hospitals, between August 2014 and July 2017. All patients fulfilled the Systemic Lupus International Collaborating Clinics (SLICC) classification criteria for SLE [16]. Exclusion criteria included patients with cardiac, chest, neurological and kidney diseases due to causes other than SLE like essential hypertension, diabetes mellitus. Also patients with urinary infection and patients undergoing renal dialysis were excluded. Written and verbal consent was taken from all subjects .

All patients were subjected to full history taking, general and locomotor examination. Assessment of disease activity in SLE patients by SLEDAI-2K score [17]. Routine laboratory investigations including $\mathrm{CBC}$, ESR, CRP, urine analysis, liver function test and kidney function test were done. Other measures of disease activity included serum complement 3 (C3), $\mathrm{C} 4$ by use of immunodiffusion plate (AMS STA., Italy) and anti DNA double stranded antibody titre done by indirect fluorescent test for detection of anti-DNA in human sera (Virgo reagents supplied by electronucleonics, Incs, Washington).

Sample Collection and Storage: Blood was collected by venipuncture, serum coagulation at room temperature 10-20 mins , centrifugation 20-min at the speed of 2000-3000 r.p.m. and supernatant is removed. Samples were assayed immediately after storage at $-20^{\circ} \mathrm{C}$ without repeated freeze-thaw cycles. Spot urine samples were collected in a sterile container, centrifugation 20-min at the speed of 2000-3000 r.p.m. and supernatant is removed.

Assessment of sIL-7R levels in samples by specific sandwich enzyme-linked immunosorbent assay ( ELISA) kit supplied by Sun Red company. SIL7R was added to monoclonal antibody enzyme which is precoated with human SIL7R monoclonal antibody, incubated. Then, we added SIL7R antibodies labeled with biotin and combined with Streptavidin-HRP to form immune complex, then incubation and washing again to remove the uncombined enzyme. After that Chromogen Solution A, B, was added, the color of the liquid changed into the blue then yellow. The chroma of color and the concentration of human sIL7R (by $\mathrm{ng} / \mathrm{ml}$ ) in samples were positively correlated.

Statistical analysis: The collected data were analyzed using the statistical package for social sciences version 13 (SPSS Inc., Chicago, USA).

\section{RESULTS}

Demographic data of patients and healthy controls: The SLE patients were 43 females and 11 males, their ages ranged from 17-48 years, with a mean of $28.9 \pm 6$ years. The control group included 17 females and 10 males. Their ages ranged from 25-35 years with a mean of $29.5 \pm 2.8$ years. There was no statistically significant difference between patients and controls as regard to age and sex. In SLE patients the most predominant clinical variable was photosensitivity (78\%), followed 
by hair falling $(61 \%)$ then nephritis $(52 \%)$, while the least frequent manifestations were pericarditis, avascular necrosis, stroke, peritonitis, pneumonitis, pulmonary hypertension and deep venous thrombosis
(1.85\%). ANA was positive in all SLE patients $(100 \%)$ while anti-dsDNA was positive in 22 patients only (40.7\%). Low C3 level was found in 18 patients $(33.3 \%)$ while low C4 level was found in 22 patients $(41 \%)$.

Table(1): Levels of both serum sIL7R and urine sIL7R of the studied groups:

\begin{tabular}{|l|l|l|l|l|}
\hline Items & $\begin{array}{l}\text { SLE patients } \\
(\mathrm{n}=54)\end{array}$ & $\begin{array}{l}\text { Controls } \\
(\mathrm{n}=27)\end{array}$ & *p & \multicolumn{1}{|c|}{ Sig } \\
\hline $\begin{array}{l}\text { Serum sIL7R } \\
\text { Mean } \pm \text { SD } \\
\text { Range (ng/ml) }\end{array}$ & $\begin{array}{c}32.3 \pm 18.7 \\
9-75.9\end{array}$ & $\begin{array}{l}7.3 \pm 6 \\
0-19\end{array}$ & 0.0001 & (HS) \\
\hline $\begin{array}{l}\text { Urine sIL7R } \\
\text { Mean } \pm \text { SD } \\
\text { Range(ng/ml) }\end{array}$ & $\begin{array}{c}7.5 \pm 6.2 \\
0-20\end{array}$ & $\begin{array}{l}7.3 \pm 6 \\
0-20\end{array}$ & 0.96 & (NS) \\
\hline
\end{tabular}

*Mann-Whtiney. $\quad \mathrm{P}<0.05$ significant

This table shows that serum levels of sIL7R were significantly higher in SLE patients ( $32.3 \pm 18.7$ $\mathrm{ng} / \mathrm{ml})$ than in control group $(7.3 \pm 6 \mathrm{ng} / \mathrm{ml})$ with $\mathrm{P}$ value 0.0001 . However the levels of urine sIL7R showed non-significant difference between both groups.

Table (2): Comparison between both serum and urine sIL7R levels in SLE patients with and without nephritis:

\begin{tabular}{|l|l|l|l|l|}
\hline Items & $\begin{array}{l}\text { SLE patients } \\
\text { with nephritis } \\
(\mathrm{n}=28)\end{array}$ & $\begin{array}{l}\text { SLE patients } \\
\text { without } \\
\text { nephritis (n=26) }\end{array}$ & *p & Sig \\
\hline $\begin{array}{l}\text { Serum sIL7R } \\
\text { Mean } \pm \text { SD } \\
\text { Range (ng/ml) }\end{array}$ & $\begin{array}{l}44 \pm 18 \\
15-75\end{array}$ & $\begin{array}{l}19.7 \pm 8 \\
9-37.5\end{array}$ & 0.0001 & (HS) \\
\hline Urine sIL7R & \multicolumn{1}{|c|}{$9 \pm 6.3$} & $\begin{array}{l}5.9 \pm 5.7 \\
0-19\end{array}$ & 0.052 & (NS) \\
Mean \pm SD & $0.1-20$ & & \\
Range(ng/ml) & &
\end{tabular}

*Mann-Whtiney

This table shows statistically high significant difference between levels of serum sIL7R in SLE patients with nephritis and those without nephritis. However, there was non -significant difference between levels of urine sIL7R in both groups.

Table (3): Relation between serum sIL7R levels and SLEDAI score in SLE patients:

\begin{tabular}{|l|l|l|l|l|l|l|}
\hline & $\begin{array}{l}\text { No } \\
(\mathrm{n}=1)\end{array}$ & $\begin{array}{l}\text { Mild } \\
(\mathrm{n}=9)\end{array}$ & $\begin{array}{l}\text { Moderate } \\
(\mathrm{n}=13)\end{array}$ & $\begin{array}{l}\text { High } \\
(\mathrm{n}=14)\end{array}$ & $\begin{array}{l}\text { v.high } \\
(\mathrm{n}=17)\end{array}$ & $\mathrm{P}$ \\
\hline $\begin{array}{l}\text { Serum } \\
\text { SIL7R }\end{array}$ & & & & & & \\
$\begin{array}{l}\text { Mean } \pm \text { SD } \\
\text { Range }\end{array}$ & 15.5 & $\begin{array}{l}14.5 \pm 4.8 \\
9-22\end{array}$ & $\begin{array}{l}18.5 \pm 6 \\
9.5-30\end{array}$ & $\begin{array}{l}29.2 \pm 6.4 \\
22-40\end{array}$ & $\begin{array}{l}55.8 \pm 12 \\
32-79.9\end{array}$ & $\begin{array}{l}0.0001 \\
(\text { HS })\end{array}$ \\
\hline
\end{tabular}


This table shows that there was statistically high significant relation between serum sIL7R levels and SLEDAI score in SLE patients.

Table (4): Levels of both Serum and urine sIL7R in lupus patients with active nephritis and those with nephritis in remission:

\begin{tabular}{|l|l|l|l|l|}
\hline & $\begin{array}{l}\text { Active } \\
\text { patients } \\
(\mathrm{n}=24)\end{array}$ & $\begin{array}{l}\text { LN patients in } \\
\text { remission } \\
(\mathrm{n}=4)\end{array}$ & Test of sig & $\mathrm{p}$ \\
\hline $\begin{array}{l}\text { Serum sIL7R } \\
\text { Mean } \pm \text { SD } \\
\text { Range }\end{array}$ & $\begin{array}{l}48 \pm 16 \\
20.02-75\end{array}$ & $\begin{array}{l}18.3 \pm 2.7 \\
15.5-22\end{array}$ & $\mathrm{t}=8.4$ & $\begin{array}{l}0.0001 \\
(\mathrm{HS})\end{array}$ \\
\hline $\begin{array}{l}\text { Urine sIL7R } \\
\text { Mean } \pm \text { SD } \\
\text { Range }\end{array}$ & $\begin{array}{l}9 \pm 6.3 \\
0.1-20\end{array}$ & $\begin{array}{l}9.7 \pm 1.9 \\
4-11.5\end{array}$ & Man-whitney & $\begin{array}{l}0.7 \\
\text { (NS) }\end{array}$ \\
\hline
\end{tabular}

LN: lupus nephritis. t: independent student t-test

This table shows statistically high significant difference of serum sIL7R in SLE patients with active nephritis and those with nephritis in remission. Levels of urine sIL7R showed nonsignificant difference between both groups.

Table (5): Correlation between serum and urine sIL7R levels and disease activity parameters of SLE patients:

\begin{tabular}{|l|l|l|l|l|}
\hline $\begin{array}{l}\text { Activity parameters of } \\
\text { SLE patients. }\end{array}$ & \multicolumn{2}{l|}{ Serum sIL7R } & \multicolumn{2}{l|}{ Urine sIL7R } \\
\hline & R & P & r & P \\
\hline Anti-dsDNA & 0.46 & $0.0001(\mathrm{HS})$ & 0.1 & $0.5(\mathrm{NS})$ \\
\hline C4 & -0.59 & $0.0001(\mathrm{HS})$ & 0.001 & $0.9(\mathrm{NS})$ \\
\hline C3 & -0.35 & $0.009(\mathrm{~S})$ & 0.22 & $0.09(\mathrm{NS})$ \\
\hline SLEDAI & 0.88 & $0.0001(\mathrm{HS})$ & 0.04 & $0.7(\mathrm{NS})$ \\
\hline
\end{tabular}

This table shows that there was highly significant positive correlation between serum IL7R levels and anti-dsDNA and SLEDAI and significantly negative correlation between serum IL7R levels and $\mathrm{C} 3$ and C4. While the correlation between urine IL7R and the activity parameters of SLE patients was non-significant. 


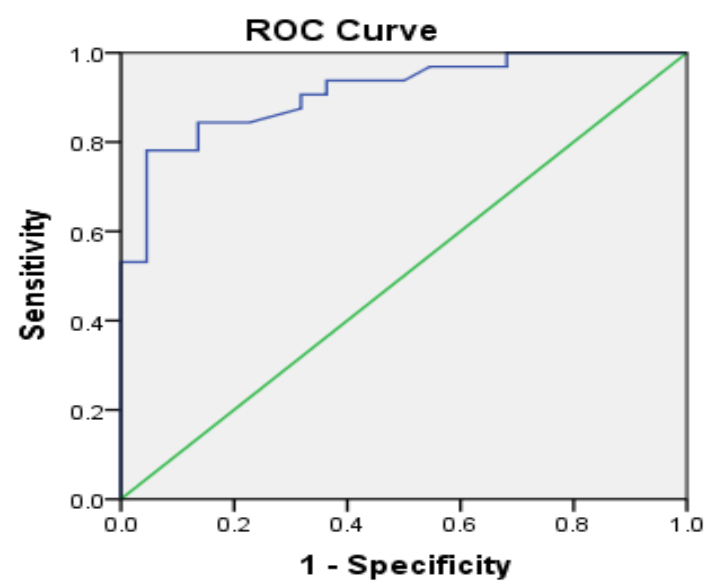

ROC curve: receiver operating characteristic curve

Figure (1): ROC curve for the validity of Serum sIL7R in SLE Patients:

This figure shows the ROC curve to determine the validity of Serum sIL7R as indicator of disease activity in SLE patients. In this figure high area under the curve 0.91 and 95\% CI (0.840.99) indicates that it has a high degree of discrimination with high accuracy as the closer the ROC curve to the upper left corner of the plot and the higher AUC, the more the accuracy and the discrimination power of the test.

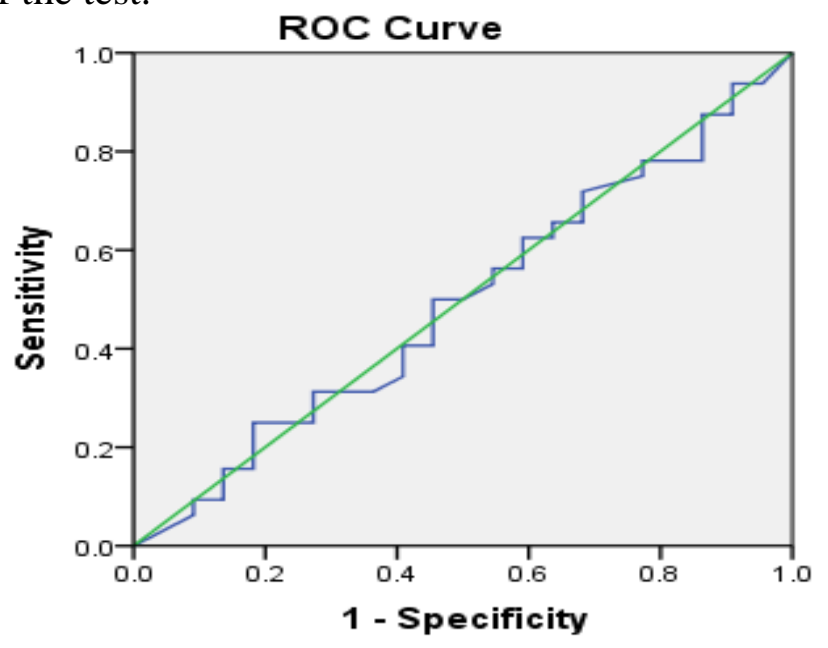

Figure (2): ROC curve for the validity of urine sIL7R in SLE Patients:

This figure shows the ROC curve to determine the validity of urine sIL7R as indicator of disease activity in SLE patients. In this figure very low area under the curve 0.49 and $95 \%$ CI $(0.34-$ $0.65)$ indicates that it has very low degree of discrimination and inaccurate.

Table (6): Comparison between sensitivity and specificity of both serum and urine sIL7R:

\begin{tabular}{|l|l|l|l|l|l|l|}
\hline & True +ve & $\begin{array}{l}\text { True } \\
-\mathrm{ve}\end{array}$ & PPV & NPV & Sensitivity & Specificity \\
\hline $\begin{array}{l}\text { Serum } \\
\text { sIL7R }\end{array}$ & 29 & 14 & $78 \%$ & $82 \%$ & $91 \%$ & $68 \%$ \\
\hline $\begin{array}{l}\text { Urine } \\
\text { sIL7R }\end{array}$ & 20 & 9 & $61 \%$ & $43 \%$ & $62.5 \%$ & $41 \%$ \\
\hline
\end{tabular}

PPV : positive predictive values. NPV: negative predictive values.

This table shows that sIL7R serum levels were highly sensitive and specific compared with the urine levels. 


\section{DISCUSSION}

This research aimed to evaluate urine and serum sIL7R levels in patients with systemic lupus erythematosus and its association with the disease activity. We also compared it with other markers of disease activity used in clinical practice such as antidsDNA antibodies titer, C3 and C4.

In our work, comparison between the serum levels of sIL7R in SLE patients and control groups were significantly higher in SLE patients $(p<0.0001)$ than in normal subjects. Moreover, we found that patients with lupus nephritis had significantly higher serum levels of sIL-7R and levels were significantly higher in those with active disease. This was in agreement with Zhou et al, 2014 [18], Lauwerys et al, 2014 [19] and Chi et al, 2016 [20].

Another study by Badot et al, 2013[21] , demonstrated that sIL-7R serum levels were raised in patients with SLE compared with healthy controls. Also, they found that serum sIL-7R levels were strongly raised in patients with active lupus nephritis and the levels decreased upon successful treatment . Immunohistochemistry on kidney biopsy samples showed abundant perivascular IL-7R expression with high TNFa in the interstitium. The absence of overexpression of sIL-7R in peripheral blood monocytes from LN patients compared with controls, and the expression of IL-7R by kidney perivascular cells, indicated that high serum sIL-7R concentrations in $\mathrm{LN}$ reflect activation of kidney tissue cells.

This explanation is supported by Badot et al, 2011[22], who found that rheumatoid arthritis synovial fibroblasts produce a soluble form of the interleukin-7receptor in response to pro-inflammatory cytokines such as $\mathrm{TNF} \alpha$, IL-1 $\beta$, IL-17.

However, in our study the urine levels of sIL7R showed non-significant difference between SLE patients and control groups and did not correlate with disease activity. Moreover, the sIL7R urine levels showed non- significant differences between patients with nephritis and those without nephritis. This was in agreement with Badot et al, 2013 [21]. However Lauwerys et al [19], differed from us as they found that there was a modest significant correlation between urine sIL7R concentrations and urinary protein to creatine ratios. They stated that it is probable that the presence of protein and sIL7R in the urinary samples is due to glomerular leakage, rather than active secretion.

In our study correlation between serum sIL7R and disease activity parameters of SLE patients revealed highly significant positive correlation with anti-dsDNA and SLEDAI. Also, there was significantly negative correlation between serum sIL7R levels and $\mathrm{C} 3$ and $\mathrm{C} 4$. These results coincided with those of Chi et al, 2016 [20] and Zhou et a, 20141 [18].

In our study sensitivity and specificity of serum sILR7 were $91 \%, 68 \%$ respectively while urine sIL7R sensitivity and specificity were $62.5 \%, 41 \%$ respectively. These results showed that serum sILR7 is better than urine sILR7 for predicting disease activity in SLE patients. Moreover, we found that serum sIL7R had high negative and positive predictive values of $82 \%, 78 \%$ respectively. These findings were supported by Lauwerys et al,2014 [19].

\section{CONCLUSION}

Serum sIL7R is a valuable marker of SLE disease activity, especially in patients with lupus nephritis.

\section{REFERENCES}

1-Golder V and Hoi A. Systemic lupus erythematosus: an update. Med J Aust. 2017; 206 (5): 215-220.

2- Gatto M, Zen M, Ghirardello A, Bettio S, , Bassi N, Iaccarino $\mathrm{L}$ et al. Emerging and critical issues in the pathogenesis of lupus. Autoimmun Rev.2013; 12(4):523-536.

3. Yap. D. Y. and Lai. K. N. Pathogenesis of renal disease in systemic lupus erythematosus - the role of autoantibodies and lymphocytes subset abnormalities. International Journal of Molecular Sciences. 2015; 16( 4): 7917-7931.

4. Jacob N. and Stohl W. Cytokine disturbances in systemic lupus erythematosus. Arthritis research and therapy. 2011; 7: 13- 228.

5- Al-Rawi M., Mansel R. and Jiang W. Interleukin-7 (IL-7) and IL-7 receptor (IL-7R) signalling complex in human solid tumours. Histol Histopathol. 2003; 18: 911-923. 
6- Wang X.S., Wen P.F., Zhang M, Hu L.F., Ni J., Qiu L-J. et al . Interleukin-7 Receptor Single Nucleotide Polymorphis rs6897932 $(\mathrm{C} / \mathrm{T})$ and the Susceptibility to Systemic Lupus Erythematosus. Inflammation. 2014; 37(2): 615-20.

7. Dooms H. Interleukin-7: fuel for the autoimmune attack. Journal of Autoimmunity. 2013; 45: 40-48.

8- Hartgring SA, Willis CR, Alcorn D, Nelson LJ, Bijlsma JW, Lafeber FP and van Roon JA. Blockade of the interleukin-7 receptor inhibits collagen-induced arthritis and is associated with reduction of $\mathrm{T}$ cell activity and proinflammatory mediators. Arthritis Rheum .2010; 62:2716- 2725.

9-van Roon JA, Verweij MC, Wijk MW, Jacobs KM, Bijlsma JW and Lafeber FP. Increased intraarticular interleukin-7 in rheumatoid arthritis patients stimulates cell contactdependent activation of CD4(+) $\mathrm{T}$ cells and macrophages. Arthritis Rheum. 2005; 52: 1700-1710.

10- Lee LF, Logronio K, Tu GH, Zhai W, Ni I, Mei L, et al. Anti-IL-7 receptor-alpha reverses established type 1 diabetes in nonobese diabetic mice by modulating effector T-cell function. Proc Natl Acad Sci U S A. 2012; 109: 12674-12679.

11-Todd JA, Walker NM, Cooper JD, Smyth DJ, Downes K, Plagnol V, et al. Robust associations of four new chromosome regions from genome-wide analyses of type 1 diabetes. Nat Genet. 2007; 39: 857-864.

12- Gregory SG, Schmidt S, Seth P, Oksenberg JR, Hart J, Prokop A, et al. Interleukin 7 receptor alpha chain (IL7R) shows allelic and functional association with multiple sclerosis. Nat Genet. 2007; 39: 1083-109.

13- Lee LF, Axtell R, Tu GH, Logronio K, Dilley $\mathrm{J}, \mathrm{Yu} \mathrm{J}$, et al. IL-7 promotes $\mathrm{T}(\mathrm{H}) 1$ development and serum IL-7 predicts clinical response

to interferon-beta in multiple sclerosis. Sci Transl Med. 2011; 3: 93ra68.

14- Willis C, Seamons A, Maxwell J, Treuting M, Nelson L, Chen G, et al. Interleukin-7 receptor blockade suppresses adaptive and innate inflammatory responses in experimental colitis. Journal of Inflammation 2012; 9:39.

15- Liu X, Leung S, Wang C, Tan Z, Wang J, Guo TB, et al . Crucial role of interleukin-7 in $\mathrm{T}$ helper type 17 survival and expansion in autoimmune disease. Nat Med. 2010; 1: 191197.

16-Petri M, Orbai AM, Alarcón GS, Gordon C, Merrill JT, Fortin PR, et al. Derivation and validation of the Systemic Lupus International Collaborating Clinics classification criteria for systemic lupus erythematosus. Arthritis Rheum. 2012; 64(8): 2677-86.

17- Gladman D.D., Ibanez D. and Urowitz M.B. Systemic Lupus erythematosus disease activity index 2000 (SLEDAI-2k ) . J Rheumatol. 2002; 29 (2): 288-291.

18- Zhou S, Jiao F, Zhou S, Li X, Lv L and Yang $X$. Relationship between serum soluble interleukin 7 receptor and disease activity in patients

with lupus nephritis. Int $\mathbf{J}$ Clin Exp Pathol. 2017; 10 (2): 2175-2180.

19- Lauwerys B. R, Husson S.N, Maudoux A.L, Badot V. and Houssiau, F.A. sIL7R concentrations in the serum reflect disease activity in the lupus kidney. Lupus Science \& Medicine.2014; 1 (1): e000036.

20- Chi S, Xue J, Li F, Zhu C, Yu Y, Li H, et al. Correlation of serum soluble interleukin-7 receptor and anti-C1q antibody in patients with systemic lupus erythematosus. Autoimmune Dis. 2016; 2016: 8252605.

21- Badot V., Luijten R.K. , Van Roon J.A., Depresseux G., Aydin S., Van den Eynde BJ. et al. Serum soluble interleukin 7 receptor is strongly associated with lupus nephritis in patients with systemic lupus erythematosus. Ann. Rheum. Dis. 2013; 72 (3): 453-456.

22- Badot V., Durez P., Van den Eynde B.J., Nzeusseu-Toukap A., Houssiau F.A., and B. R. Lauwerys B.R. Rheumatoid arthritis synovial fibroblasts produce a soluble form of the interleukin-7 receptor in response to proinflammatory cytokines. Journal of Cellular and Molecular Medicine. 2011; 15 (11): 23352342. 